\title{
POSITIVE INTERACTION OF INDUSTRIAL AND RECYCLED STEEL FIBRES IN FIBRE REINFORCED CONCRETE
}

\author{
Dubravka BJEGOVIC ${ }^{\mathrm{a}}$, Ana BARICEVIC ${ }^{\mathrm{a}}$, Stjepan LAKUSIC ${ }^{\mathrm{b}}$, \\ Domagoj DAMJANOVIC ${ }^{\mathrm{c}}$, Ivan DUVNJAK ${ }^{\mathrm{c}}$ \\ ${ }^{a}$ Faculty of Civil Engineering, Department of Materials, University of Zagreb, \\ Fra Andrije Kacic Miosic 26, 10000 Zagreb, Croatia \\ ${ }^{b}$ Faculty of Civil Engineering, Department of Transportation, University of Zagreb, \\ Fra Andrije Kacic Miosic 26, 10000 Zagreb, Croatia \\ ${ }^{c}$ Faculty of Civil Engineering, Department of Engineering Mechanics, University of Zagreb, \\ Fra Andrije Kacic Miosic 26, 10000 Zagreb, Croatia
}

Received 25 Jan 2012; accepted 05 Nov 2012

\begin{abstract}
In line with current "green" transport initiatives, Croatia plans to build over the next investment period a high speed railway line which will connect central Croatia and its capital with coastal regions of the country. According to design documents, the track system will be built using ballastless concrete solutions. In the scope of the project "Concrete track system - ECOTRACK", researchers from the University of Zagreb - Faculty of Civil Engineering analysed a new material, i.e. the rubberized hybrid fibre reinforced concrete (RHFRC), in order to find out whether its properties are adequate for the proposed concrete track system. The RHFRC contains by-products from mechanical recycling of waste tyres (rubber and steel fibres). The study of fibre and rubber interaction and their contribution to mechanical properties of the fibre reinforced concrete is presented, as extensive research on positive interaction between industrial and recycled steel fibres has not as yet been made. The results show that the RHFRC is an innovative, sustainable and cost-effective concrete, which is fully compliant with criteria prescribed in relevant standards.
\end{abstract}

Keywords: fibre reinforced concrete, industrial steel fibres, recycled steel fibres, mechanical properties, recycled rubber, waste tyre.

Reference to this paper should be made as follows: Bjegovic, D.; Baricevic, A.; Lakusic, S.; Damjanovic, D.; Duvnjak, I. 2013. Positive interaction of industrial and recycled steel fibres in fibre reinforced concrete, Journal of Civil Engineering and Management 19(Supplement 1): S50-S60. http://dx.doi.org/10.3846/13923730.2013.802710

\section{Introduction}

Until recently, Croatian investments mostly focused on the construction of one segment of transport infrastructure - motorways. After becoming the EU candidate, Croatia became more oriented towards sustainable development and soon it became clear that "green" transport alternatives must be strengthened. In the oncoming period, Croatia plans to build a high speed railway line, which will connect central Croatia and its capital with coastal regions of the country. According to the design documentation, the track system will be based on ballastless concrete solutions.

During realization of the project "Concrete track system - ECOTRACK", researchers from the University of Zagreb studied a new material, i.e. the rubberized hybrid fibre reinforced concrete (RHFRC), which could prove suitable for the proposed track system (Fig. 1).

As the material most commonly used in the construction of balastless concrete track systems, ordinary

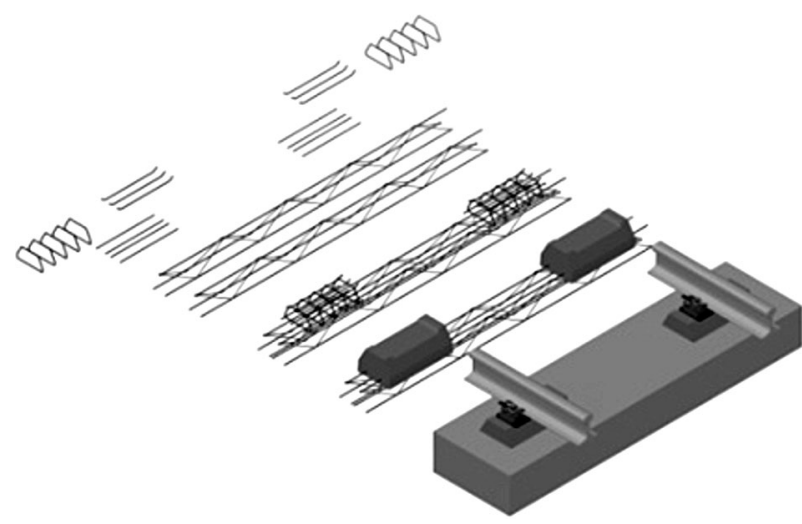

Fig. 1. ECOTRACK - concrete track system based on innovative, environmentally friendly materials

concrete presents many disadvantages such as the low energy absorption capacity, poor post-cracking behaviour, and therefore inadequate durability (Fig. 2). In this paper, fibre reinforced concrete with by-products from mechan-

Corresponding author: Ana Baricevic

E-mail:abaricevic@grad.hr 


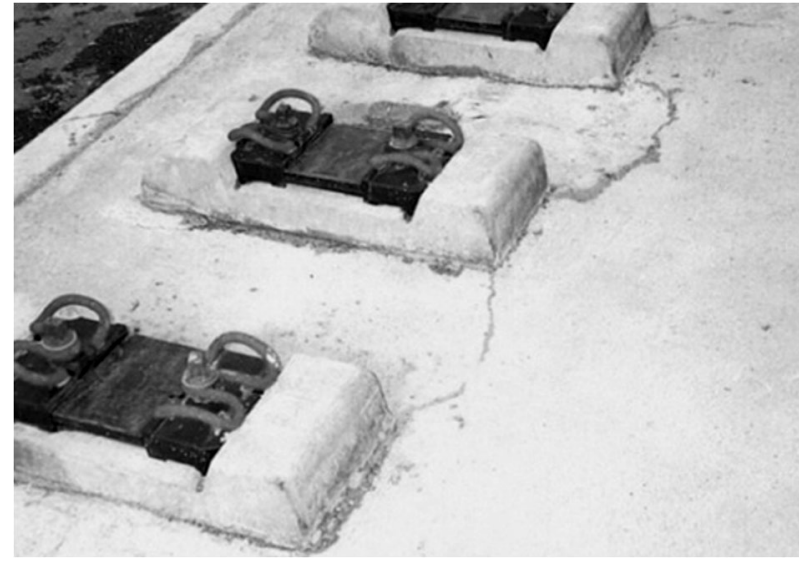

Fig. 2. Problems encountered during use of the concrete ballastless track System

ical recycling of waste tyres (rubber and steel fibres), is studied in order to obtain an adequate alternative to ordinary concrete.

Steel fibres are often used as crack arrestors and contributors to strength, deformability and toughness of composites. By reducing crack openings, improving ductility, energy absorption and post-cracking strength of composites, steel fibres are rightly considered as an optimum solution. The aim of this study is to determine a positive synergy between industrial and recycled steel fibres. Additionally, rubber is incorporated to assure enhancement of the concrete energy absorption capacity.

The waste management protocol for the oncoming period is clearly defined in numerous EU Directives, and so the research in this field has become attractive from both economic and environmental standpoints. Starting from 2006, any kind of waste tyre disposal is forbidden (Council of the European Union 1999) and, at the same time, 6200 waste tyres are reused with each kilometre of railway built using the studied material, which has brought about extensive improvements in the sphere of waste tyre management. On the other hand, an extremely high price of industrially processed steel fibres (approximately $1500 € / t$ ) has resulted in the rise of price per each $\mathrm{m}^{3}$ of concrete, which further justifies this research, especially if the price of recycled fibres is taken into account (approximately $150 € / \mathrm{t}$ ).

\section{Application of recycled steel fibres in concrete technology}

Several processes can be used to recover recycled steel fibres from waste tyres: the shredding and cryogenic process for mechanical recovery, or the pyrolysis and microwave induced pyrolysis for recovery utilising thermal degradation (Pilakoutas et al. 2004). Previous research in this field mainly consisted in the study of fibre reinforced concrete properties and focused exclusively on recycled steel fibres, and comparison with steel fibre reinforced concrete containing industrial steel fibres (Achilleos et al. 2011; Aiello et al. 2009; Graeff et al. 2009; Ne- ocleous et al. 2006; Tlemat et al. 2004). Recent studies (Graeff et al. 2012) on fatigue resistance of concrete pavements reinforced with recycled steel fibres suggests that for enhanced fatigue performance a combination of recycled and industrially produced fibres would be ideal. Possible synergy of recycled and industrial steel fibres has until now been briefly investigated in few papers only (Angelakopoulos et al. 2011; Bjegovic et al. 2012a, b, c; Krolo et al. 2012).

Steel fibres obtained by shredding during the recycling process are irregular in shape and dimensions, and so their ability to provide for an effective stress transfer was considered questionable. Despite irregular undulations it was demonstrated that steel fibres obtained during the shredding process give an effective mechanical contribution to the bond performance (Aiello et al. 2009), and that their strength is best utilized when the used length ranges between 20 to $50 \mathrm{~mm}$ (Pilakoutas et al. 2004). To obtain an optimum length, and to reduce intensive labour during manual incorporation of recycled steel fibres into the mixture, an appropriate sorting treatment has been developed (Neocleous et al. 2011). The investigation of fibre reinforced concrete with recycled steel fibres implies that it has similar structural performance as the one prepared with industrially produced steel fibres, i.e. that it has an adequate energy absorption and good residual strength after cracking (Aiello et al. 2009). If more recycled steel fibres are added to the mixture, the postpeak flexural behaviour is similar to that of the ordinary fibre reinforced concrete (mixture with $2 \%$ industrial and $6 \%$ recycled steel fibres by weight are comparable) (Achilleos et al. 2011; Neocleous et al. 2011).

Parallel investigations were conducted to confirm positive synergy between steel fibres and rubber particles. According to the Turatsinze et al. (2005), the strain capacity before macrocracking localization is improved by rubber aggregate substitution. It was demonstrated that the presence of rubber particles in the mixture does not affect the ability of industrial steel fibres to transfer stress, i.e. that the post-peak behaviour improves with an increase in the amount of industrial steel fibres. In their research, Turatsinze et al. (2006) imply that as a low modulus aggregate, rubber particles act as crack arresters while steel fibres present a crack control mechanism, which is an indication of positive synergy between rubber particles and industrial steel fibres. It was therefore concluded that the efficiency of industrially produced steel fibres does not change even when cementitious materials are rubberized (Nguyen et al. 2010).

Meanwhile, Papakonstantinou and Tobolski (2006) conducted research on possible use of steel beads in concrete as an alternative to the steel fibre reinforced concrete. Steel beads usually contain $30 \%$ of recycled steel fibres and $70 \%$ of rubber particles. Relevant research results show that with the use of $2 \%$ of steel beads per volume, the compressive strength reduces by $2 \%$, while at the same time the ductility increases by $20 \%$. Possi- 
ble disadvantage of the steel beads use in concrete is the interlocking problem which causes significant local worsening of concrete properties in localized high steel and rubber areas.

After proper analysis of the above mentioned research results, it was established that an extensive research is needed about positive interaction between industrial and recycled steel fibres. Based on previous results, the authors have concluded that an economically viable hybrid fibre reinforced concrete can be prepared by joint use of industrial and recycled steel fibres. Since positive synergy of industrially produced steel fibres and rubber particles has already been demonstrated, the study was extended to determine positive synergy between the hybrid fibre reinforced concrete and rubber particles in order to evaluate rubber contribution to the properties of the rubberized hybrid fibre reinforced concrete (RHFRC).

\section{Experimental work}

\subsection{Materials and mix proportions}

Experimental work presented in this paper was conducted during the project "Concrete track systems ECOTRACK". After analysis of problems that were registered in the previously constructed concrete track systems, researchers from the University of Zagreb developed an innovative low cost material to be used for the above mentioned purpose. In the course of investigations, more than 1000 concrete specimens were cast and prepared in keeping with mix proportions given in Table 1. Only a part of the research is presented in this paper.

The main aim of the research was to prepare the hybrid fibre reinforced concrete through investigation of interaction between industrial and recycled steel fibres with or without incorporation of rubber particles in the amount of $5 \%$ of the total volume of aggregate. Three different fibre ratios (100IOR, 50I50R, 0I100R; abbreviation: $100 \mathrm{I} 0 \mathrm{R}=100 \%$ industrial fibre and $0 \%$ recycled fibre in the total fibre content) were selected and their influence on concrete properties was examined. The fibre content was kept constant, $30 \mathrm{~kg}$ per $\mathrm{m}^{3}$, in order to examine the influence of fibre synergy, and to reduce "the balling effect" which is especially pronounced when recycled fibres are used in the mixture.
Mixtures were prepared with CEM II/BM SV $42.5 \mathrm{~N}$, combination of four fraction $(0-4,4-8,8-16$, $16-32 \mathrm{~mm}$ ) crushed and alluvial aggregate, addition of silica fume and superplasticizer (polycarboxylic ether hyperplasticiser). A Croatian company for mechanical recycling of waste tyres supplied by-products needed in the investigation: rubber particles $(0.5-2 \mathrm{~mm})$ and steel fibres (irregular shape and dimension). Information on geometrical variability of the recycled steel fibres (in terms of length) is presented in the histogram (Figs 3 and $4 \mathrm{~b}$ ). Diameter amounts $0.18 \pm 0.029 \mathrm{~mm}$. Due to the relatively short length of the recycled fibres used in this study (majority have length less than $15 \mathrm{~mm}$ ) it is expected that they cannot be as effective as recycled fibres with longer lengths. Industrial fibres, $35 \mathrm{~mm}$ long with $0.55 \mathrm{~mm}$ diameter and bent ends, were used as reference (Fig. 4 a).

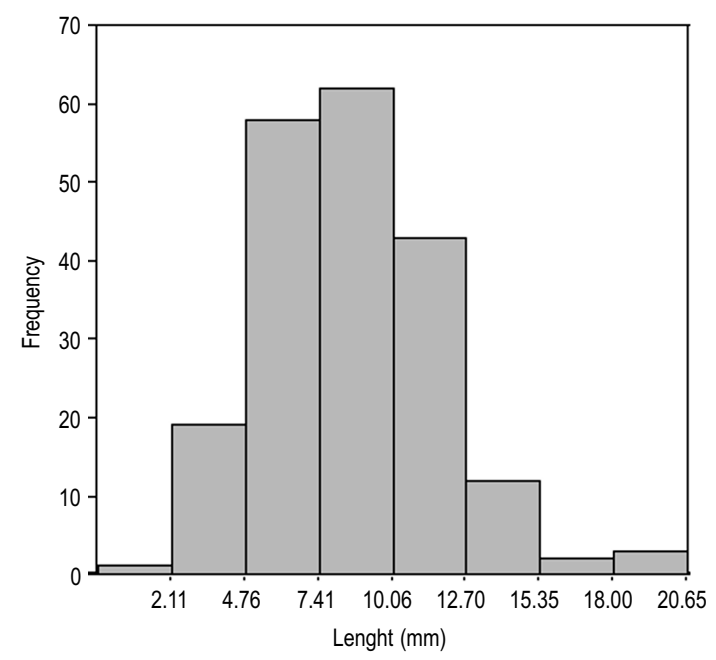

Fig. 3. Information on the geometrical variability of the recycled steel fibres (in terms of length)

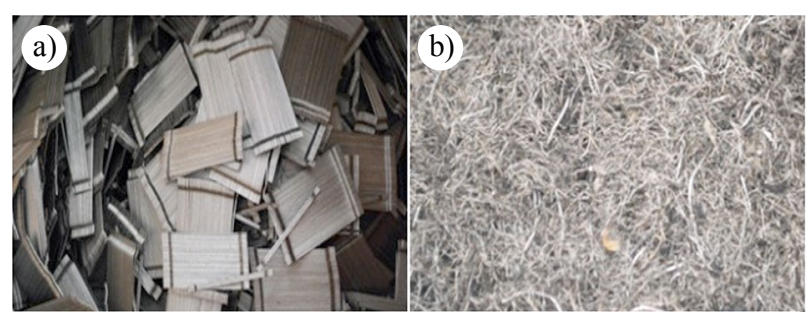

Fig. 4. Industrial steel fibres (a); Recycled steel fibres (b)

Table 1. Mixture composition

\begin{tabular}{ccccccccc}
\hline Mixture & $\begin{array}{c}\text { Cement } \\
(\mathrm{kg})\end{array}$ & $\begin{array}{c}\text { Water } \\
(\mathrm{l})\end{array}$ & $\begin{array}{c}\text { Aggregate } \\
(\mathrm{kg})\end{array}$ & $\begin{array}{c}\text { Superpla- } \\
\text { sticizer }(\mathrm{kg})\end{array}$ & $\begin{array}{c}\text { Silica fume } \\
(\mathrm{kg})\end{array}$ & $\begin{array}{c}\text { Industrial } \\
\text { fibres }(\mathrm{kg})\end{array}$ & $\begin{array}{c}\text { Recycled } \\
\text { fibres }(\mathrm{kg})\end{array}$ & $\begin{array}{c}\text { Rubber } \\
(\mathrm{kg})\end{array}$ \\
\hline 100I0R & 420 & 170 & 1743 & 2.31 & 21 & 30 & 0 & 0 \\
\hline 50I50R & 420 & 170 & 1743 & 2.31 & 21 & 15 & 0 & 15 \\
\hline 0I100R & 420 & 170 & 1743 & 2.31 & 21 & 0 & 30 & 0 \\
\hline 100I0RG & 420 & 170 & 1656 & 2.31 & 21 & 30 & 15 & 18.90 \\
\hline 50I50RG & 420 & 170 & 1656 & 2.31 & 21 & 15 & 0 \\
\hline 0I100RG & 420 & 170 & 1656 & 2.31 & 21 & 0 & 30 & 18.90 \\
\hline
\end{tabular}

Abbreviation: $\mathrm{I}=$ industrial fibres; $\mathrm{R}=$ recycled fibres; $\mathrm{G}=$ rubber granulates 
When used in cementitious composites, rubber is usually pre-treated so that a good quality bond at the rubber/cement paste interface can be achieved. According to literature data (Segre, Joekes 2000; Marques et al. 2004; Segre et al. 2002), different rubber pre-treatments are available, but the one most often applied is immersion in the saturated sodium hydroxide solution. Meanwhile, due to a high amount of alkaline in concrete during the exposure period, the presence of sodium hydroxide could be the determinant factor for the composite's durability (Marques et al. 2008). The research previously conducted by the authors (Bjegovic et al. 2011, 2010; Lakusic et al. 2011) implies that the concrete durability can be increased if the sodium hydroxide is replaced with calcium hydroxide.
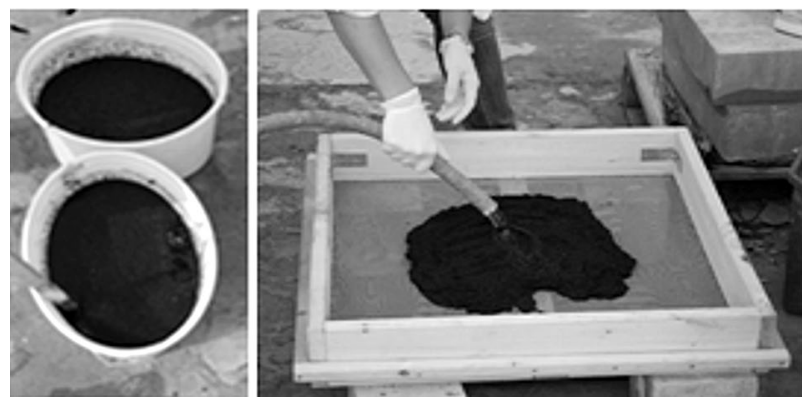

Fig. 5. Pre-treatment of rubber particles in the saturated calcium hydroxide solution

During the investigation, the rubber particles were initially pre-treated in the saturated calcium hydroxide solution, then rinsed in potable water, and added to the mixture (Fig. 5) (Lakušić et al. 2012). A detailed research on the influence of calcium hydroxide is now under way.

\subsection{Test methods}

Three specimens were prepared for each mixture for each test. They were demoulded after $24 \mathrm{~h}$, and then cured. The testing of concrete properties in fresh and hardened state was performed according to appropriate procedures (Table 2), including testing of toughness and impact resistance.

Table 2. Testing and appropriate procedures

\section{Test method}

Density (EN 12350-6:2009)

Air content (EN 12350-7:2009)

Slump test (EN 12350-2:2009)

Compressive strength (EN 12390-3:2009)

Modulus of elasticity (HR U.M1.025)

\section{Evaluation of flexural toughness}

Evaluation of flexural toughness was performed using the following procedures: ASTM C1018, ASTM 1609, and RILEM TC 162-TDF (American Society for Testing and Materials 1998, 2008; RILEM TC 162 - TDF 2002). The above mentioned standards were used to gain better understanding of the composite's ability to withstand certain loads and deformations without degradation. Toughness is a measure of the energy absorption capacity of a material, and it is used to characterize ability of materials to resist fracture when subjected to static strain or dynamic or impact load (ACI Committee 544 2009).

Although each of the standards is related to specified conditions and geometry, toughness parameters are used in this paper for quantitative comparison only. Toughness parameter values obtained from different standards are used to compare performance of various fibre reinforced concrete types, differing from one another by the quantity of recycled steel fibres and/or rubber granulates.

The flexural performance was evaluated using the three-point load test over the $50 \mathrm{~cm}$ span, on prismatic specimens $(15 \times 15 \times 55 \mathrm{~cm})$, with $6 \mathrm{~cm}$ notch (Karihaloo 1995). The bending test was performed using the electro-mechanical testing machine Zwick Z600E with the vertical displacement control. Rate of increase of net deflection was $0.05 \mathrm{~mm} / \mathrm{min}$ up to $\mathrm{L} / 600$ of net deflection and $0.15 \mathrm{~mm} / \mathrm{min}$ after that. The force was measured using the $50 \mathrm{kN}$ load cell, class 0.5 . To enable the threepoint loading of specimens without eccentricity or torque, fixtures with the supporting roller were used, which enabled rotation without any restraints. Two LVDT-sensors (HBM WA 10, class 0.5) were mounted on each side of the specimen to measure vertical deflection. The test setup is presented in Fig. 6.

The standard method according to ASTM C1018 was used to determine toughness indices $\left(\mathrm{I}_{5}, \mathrm{I}_{10}, \mathrm{I}_{20}\right)$. These indices were calculated by dividing the area under load deflection curve up to the prescribed deflection - with the area under the load - deflection curve up to the first crack deflection. The behaviour of the material up to the selected deflection was described based on the toughness index values. Residual strength factors were determined from
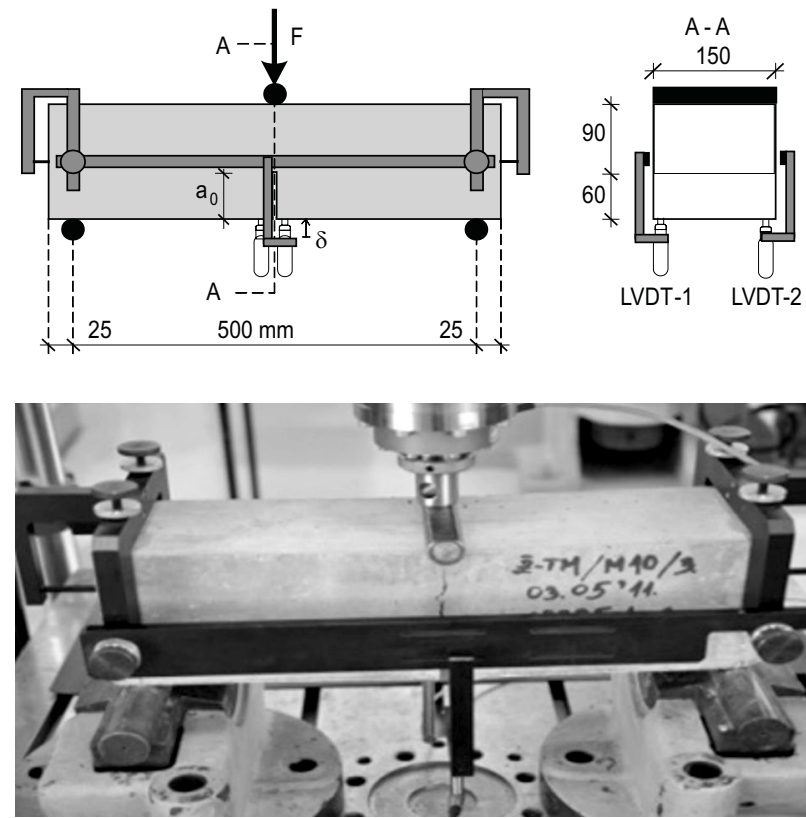

Fig. 6. Test setup for the three point bending test 
the toughness indices. Residual strength factors $\left(\mathrm{R}_{5,10}\right.$, $\mathrm{R}_{10,20}$ ) represent the level of strength retained, by expressing the average post-crack load over a specific deflection interval as a percentage of the load at first crack.

The flexural toughness can be evaluated using the ASTM C1609 standard in which main toughness parameters are based on load - deflection curve recorded during the static flexural testing. The following typical points can be seen at the diagram: the first peak load and residual load correspond to specified deflections (L/ and $L / 150$ ). The first-peak strength, $f_{p}$ is used to characterize flexural behaviour of the fibre reinforced concrete until appearance of first cracks, while residual strengths are used to describe the residual capacity of concrete after cracking, $\mathrm{f}_{\mathrm{L} / 600}$ and $\mathrm{f}_{\mathrm{L} / 150}$. The toughness, $\mathrm{T}_{\mathrm{L} / 150}$ is presented as a measure of energy absorption of tested specimens, and can be determined as the total area under the load-deflection curve.

The tensile behaviour of the fibre reinforced concrete can even be determined according to the RILEM recommendation TC 162-TDF. Its tensile behaviour is evaluated in terms of area under the load-deflection curve, or by the load bearing capacity at a particular deflection. The load at the limit of proportionality, $\mathrm{f}_{\mathrm{ct}, \mathrm{L}}$ and the equivalent strengths, $\mathrm{f}_{\mathrm{eq}, 1}$ and $\mathrm{f}_{\mathrm{eq}, 3}$ are determined from the load-deflection curves at certain deflections. The energy absorption capacity is made of two parts: for plain concrete and from the influence of steel fibres. Accordingly, the energy absorption capacity was determined up to the following deflections: $\delta_{\mathrm{L}}+0.65 \mathrm{~mm}$ and $\delta_{\mathrm{L}}+2.65 \mathrm{~mm}$, where $\delta_{\mathrm{L}}$ is deflection of the limit of proportionality.

ASTM 1018 suffered from a number of drawbacks such as accurate measurement of first part of load vs. deflection curve, influence of determining of the first crack point to calculated toughness parameters, specimen size, insensibility of toughness indices to fibre type and volume (Chen et al. 1995; Gopalaratnam et al. 1991). As a result of these problems, ASTM C1018 was withdrawn in 2006 and replaced by ASTM C1609. The new standard represents an improvement but there are still some problems when it is applied to materials exhibiting deflection-hardening behaviour (Kim et al. 2008; Skazlić, Bjegović 2009).

Barr and Lee $(2003 a, b)$ conducted a round robin test programme on the beam bending test recommended by RILEM TC 162-TDF. They found the recommended test is a good and robust testing system, although some minor inter-lab variations do occur. It was also concluded that toughness can be evaluated either from $\mathrm{P}-\delta$ or P-CMOD curves and that relationship between these curves needs to be established for any given geometry.

\section{Evaluation of impact resistance or dynamic strength}

An improved impact resistance (dynamic energy absorption and strength) is an important attribute of FRC. The impact strength is described as the number of blows in a "repeated impact" test that is needed to achieve the prescribed level of distress (ACI Committee 544 2009). The instrumented drop-weight type impact test was performed during evaluation of the HRFC impact strength. The testing was performed using the gravity drop hammer guided by two columns (Fig. 7).

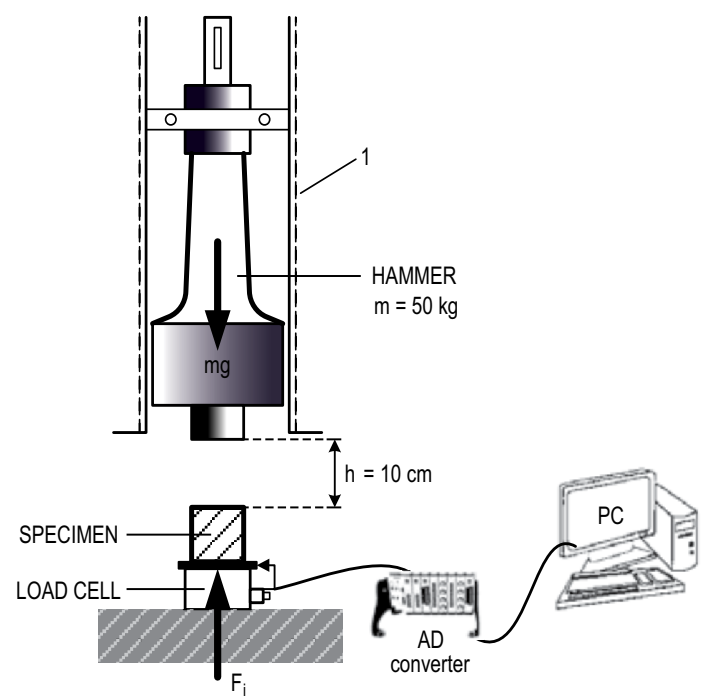

Fig. 7. Layout of the instrumented drop weight system

The weight of the hammer $(50 \mathrm{~kg})$ and the drop height $(10 \mathrm{~cm})$ provide impact velocities and energy capacities for the test. The load of the falling hammer is transferred onto the specimen $(7 \times 7 \times 7 \mathrm{~cm})$ placed on the force transducer (500 kN load cell, type HBM, C6A). The force transducer is connected to the $\mathrm{AD}$ converter (National Instruments CompactDAQ) and a computer, which ensures a high speed acquisition of force signal over time (sampling frequency $50 \mathrm{MHz}$ ).

Specific impact energy increases with specimen size, particularly for high strength concrete (Mindess, Rieder 1999). Choosing relatively small specimens authors wanted to determine characteristic impact resistance of tested mixtures with reasonable number of blows, although these results won't be comparable to results of test performed on larger specimens.

\section{Results and discussion}

The analysis of earlier studies reveals that extensive research is needed on possible interaction between industrial and recycled fibres. Additionally, rubber is incorporated to assure enhancement of the concrete energy absorption capacity. Possible synergy of industrial and recycled steel fibres could result in significant economic savings, and also in considerable environmental benefits, without influencing concrete properties, which is why this material can rightly be characterized as extremely viable. 


\subsection{Properties of concrete in fresh state}

Benazzouk et al. (2006) and Khaloo et al. (2008) indicate that rubber particles have the capability to entrap air, due to their rough surface and non-polar nature. The presence of $5 \%$ of rubber particles in the total volume of the aggregate did not cause considerable changes in concrete microstructure (Table 3). Small amount of entrapped air obtained in composites with rubber particles is due to better filling of empty pores at the rubber/cement interface, because of the presence of silica fume in the composite.

Table 3. Properties of concrete in fresh state

\begin{tabular}{cccc}
\hline Mixture & Density $\left(\mathrm{kg} / \mathrm{m}^{3}\right)$ & Porosity $(\%)$ & Slump $(\mathrm{mm})$ \\
\hline 100I0R & 2.4756 & 2.30 & 50 \\
\hline 50I50R & 2.4550 & 2.30 & 55 \\
\hline 0I100R & 2.4894 & 2.30 & 60 \\
\hline 100I0RG & 2.4331 & 1.50 & 120 \\
\hline 50I50RG & 2.4169 & 2.00 & 70 \\
\hline 0I100RG & 2.4475 & 2.30 & 45 \\
\hline
\end{tabular}

Guneyisi et al. (2004) indicate that 5\% of rubber particles in the total volume of aggregate can be considered negligible in terms of concrete workability. On the contrary, the presence of steel fibres is associated with the decrease in concrete workability due to fibre tendency to interlock during the mixing process, which is also known as the "balling" effect (Neocleous et al. 2011).

The authors believe that the decrease in workability obtained in this research is due to restrained conditions during concreting. Namely, due to the restricted conditions in the laboratory at the Faculty of Civil Engineering of the University of Zagreb, the specimens were prepared in a precast concrete plant. The coarseness of the precast concrete plant technology was minimised by manual placement of all components into the mixer. The aggregate was taken from the silo and kept in the closed space to obtain saturated surface dry conditions. During concreting, the quantity of all components was kept constant without correction of water to retain constant consistency class. It is therefore considered that the obtained differences in consistency class are due to aggregate humidity rather than to the incorporation of rubber and/or steel fibres (Table 3). Differences in consistency class were taken into account in subsequent analysis.

Low density of rubber significantly influences the concrete density in fresh and hardened state, which is dependent on the total quantity of rubber incorporated in the mixture. The quantity of rubber particles used during this research was too small to cause changes in the fresh concrete unit weight (Table 3).

\subsection{Compressive strength}

The concrete used for construction of special structures, such as high speed railways, has to meet several criteria in order to be able to achieve adequate mechanical and

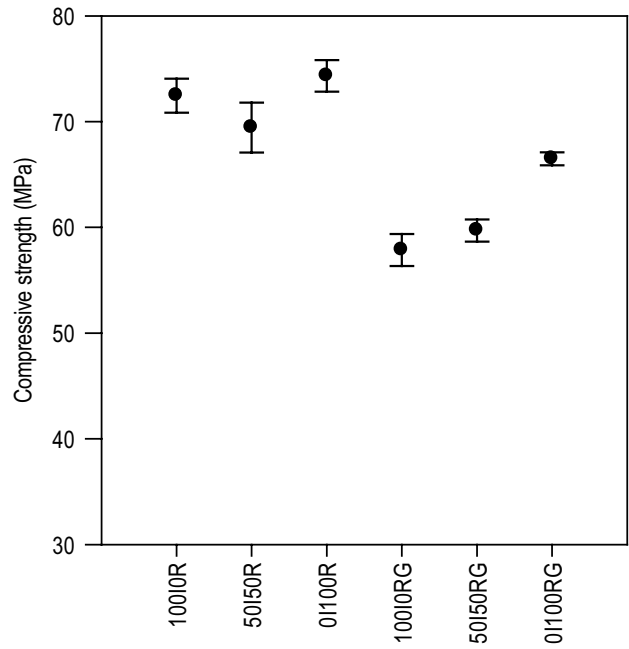

Fig. 8. Mean compressive strength for mixtures with or without rubber particles

durability performance. According to the relevant standard, the minimum compressive strength class of concrete should be $\mathrm{C} 45 / 55$.

The influence of each component is analysed taking into account differences in consistency class (Table 3$)$. The incorporation of rubber particles (5\% by total volume of aggregate) was not a restraining factor in achievement of an adequate compressive strengths class (Fig. 8). Consequently, even though the rubber/cement paste interface is of inadequate quality due to paucity of the interface, its influence on the concrete microstructure can be considered negligible. Rubber composites exhibit an average decrease of $15 \%$ of the compressive strength, when compared to the ordinary fibre reinforced concrete.

Recycled steel fibres did not cause variations in compressive strength. Current differences between composites with different fibre ratios were the consequence of consistency class.

\subsection{Modulus of elasticity}

Khorami et al. 2007 point to the differences between rubber particles and natural aggregate, with regard to modulus of elasticity; modulus of elasticity of rubber is 25 to 25000 times lower when compared to that of natural aggregate. Rubber can therefore withstand large deformations, as it acts like a spring inside the composite and delays crack widening, as well as catastrophic failures (Aules 2011).

Turatsinze et al. (2006) imply that rubber contributes to stress transfer when an external load is applied to the composite. The described behaviour is dependent on the quantity of rubber in the composite, and cannot be correlated with the presence of steel fibres (Nguyen et al. 2010) (Fig. 9). A high modulus of elasticity of steel fibres has no influence on the composite's modulus of elasticity due to fibre minor contribution in terms of volume (Domagała 2011).

Accordingly, regardless of the kind of steel fibres present in the composite, if the total volume is kept con- 


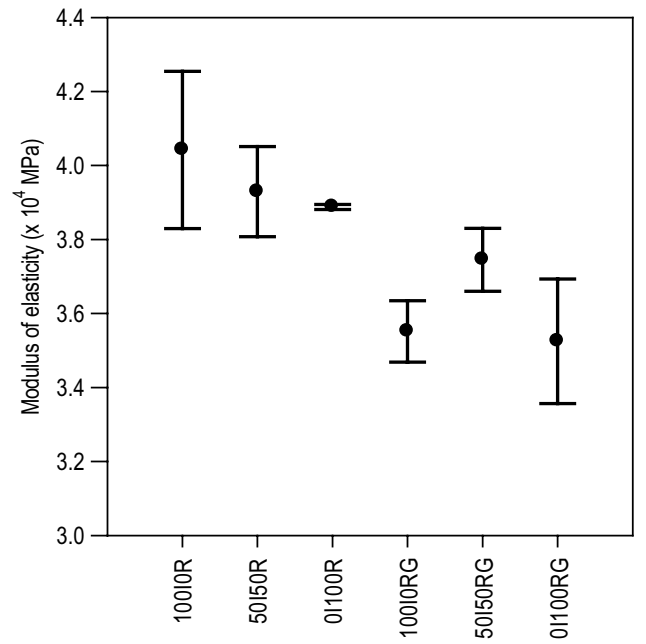

Fig. 9. Mean modulus of elasticity for mixtures with or without rubber particles

stant, there will be no significant change in the modulus of elasticity. Due to the incorporation of rubber particles, an average decrease amounts to $9 \%$.

\section{Toughness}

Rubber particles exert a positive influence on the toughness of the composite, because they have a great capacity to absorb dynamic loads and resist crack propagation, especially if compared to ordinary concrete ( $\mathrm{Li}$ et al. 2004). The examination of load - deflection curves confirms higher toughness of rubberized composites, which allows for greater deformation without disintegration (Jingfu et al. 2008). A similar behaviour has been noted in fibre reinforced composites, where steel fibres hold the micro cracking mechanism and limit crack propagation, and so toughness and ductility are improved (Papakonstantinou, Tobolski 2006). The study of positive synergy between industrial steel fibres and rubber particles shows that the ability of fibres to transfer stress across the crack is not affected if rubber is present. The interaction between them shows that rubber aggregates act as crack arresters while fibres are conferring crack control mechanisms (Turatsinze et al. 2005, 2006).
No research has so far been performed on the interaction between industrial and recycled steel fibres during the post-cracking period. The tensile behaviour of the rubberized hybrid fibre reinforced concrete was evaluated according to the load bearing capacity at a particular level of deflection (Fig. 10). The used recycled fibre type did not affect much the peak flexural strength of the composite. Design parameters $\mathrm{f}_{\mathrm{fct}}, \mathrm{f}_{\mathrm{eq} 2}$ and $\mathrm{f}_{\mathrm{eq}} 3$ defined by RILEM TC 162-TDF were calculated. To provide quantitative comparison, the flexural behaviour was also evaluated according to the ASTM C1609 and ASTM C1018 standard methods (Table 4, Figs 11 and 12).

Since, it was determined that a higher quantity of recycled steel fibres in the composite causes some decrease of the composite's toughness compared to the ordinary fibre reinforced concrete, and additional optimisation was made by incorporating rubber particles in the amount of $5 \%$ of the total volume of the aggregate.

The results point to the positive synergy between the fibre reinforced concrete and rubber granulates. It can be observed that although mixtures without rubber usually have higher flexural strength at first crack, the rubberized concrete exhibits a higher energy absorption capacity during the post-cracking period, and hence higher values of residual strength. The rubberized fibre reinforced concrete has on an average 16\% higher flexural strength at final deflection of $3.00 \mathrm{~mm}$, compared to mixtures without rubber particles (Figs 11 and 12).

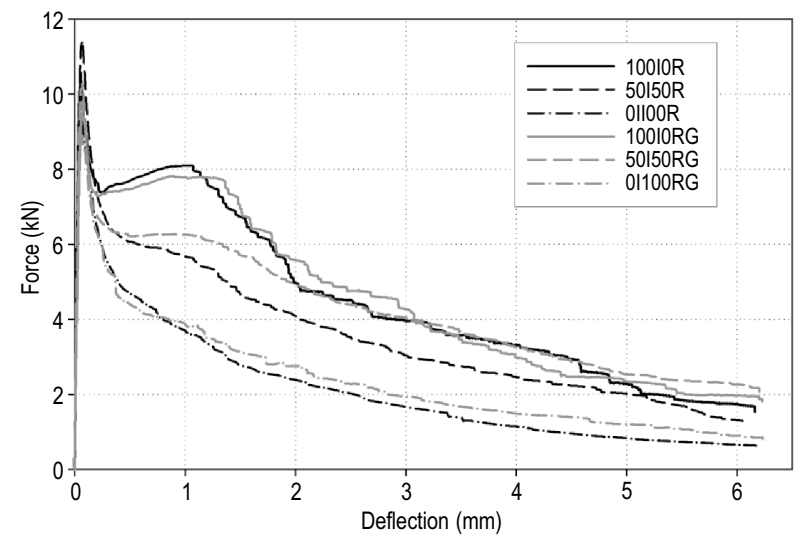

Fig. 10. 28 day splitting tension load - deflection curves

Table 4. Evaluation of tensile flexural behaviour

\begin{tabular}{|c|c|c|c|c|c|c|c|c|c|c|c|c|}
\hline \multirow{3}{*}{ Mixture } & \multicolumn{3}{|c|}{ RILEM TC 162-TDF } & \multicolumn{4}{|c|}{ ASTM C1609 } & \multicolumn{5}{|c|}{ ASTM C1018 } \\
\hline & $\mathrm{f}_{\mathrm{fct}, \mathrm{L}}$ & $\mathrm{f}_{\mathrm{eq}, 2}$ & $\mathrm{f}_{\text {eq, } 3}$ & $f_{p}$ & $\mathrm{f}_{\mathrm{L} / 600}$ & $\mathrm{f}_{\mathrm{L} / 150}$ & $\mathrm{~T}_{\mathrm{L} / 150}$ & $\mathrm{I}_{5}$ & $\mathrm{I}_{10}$ & $\mathrm{I}_{20}$ & $\mathrm{R}_{5,10}$ & $\mathrm{R}_{10,20}$ \\
\hline & & $\left(\mathrm{N} / \mathrm{mm}^{2}\right.$ & & & $\left(\mathrm{N} / \mathrm{mm}^{2}\right.$ & & $(\mathrm{Nm})$ & & & & & \\
\hline 100I0R & 6.47 & 4.15 & 3.91 & 6.52 & 4.75 & 2.13 & 20.10 & 3.72 & 6.46 & 12.03 & 54.7 & 55.7 \\
\hline $50 \mathrm{I} 50 \mathrm{R}$ & 6.53 & 3.63 & 2.96 & 7.05 & 3.60 & 1.55 & 15.63 & 3.41 & 5.65 & 9.72 & 44.8 & 40.7 \\
\hline 0I100R & 5.74 & 2.62 & 1.92 & 6.07 & 2.34 & 1.00 & 10.56 & 3.36 & 5.38 & 8.67 & 40.4 & 32.8 \\
\hline 100I0RG & 5.75 & 4.40 & 4.06 & 6.06 & 4.76 & 2.39 & 20.79 & 3.65 & 6.54 & 12.38 & 57.7 & 58.4 \\
\hline 50I50RG & 5.85 & 3.69 & 3.39 & 6.35 & 3.86 & 2.35 & 17.96 & 3.37 & 5.78 & 10.41 & 48.2 & 46.2 \\
\hline 0I100RG & 5.28 & 2.46 & 1.85 & 5.48 & 2.23 & 1.04 & 10.19 & 3.37 & 5.5 & 8.87 & 42.5 & 33.7 \\
\hline
\end{tabular}



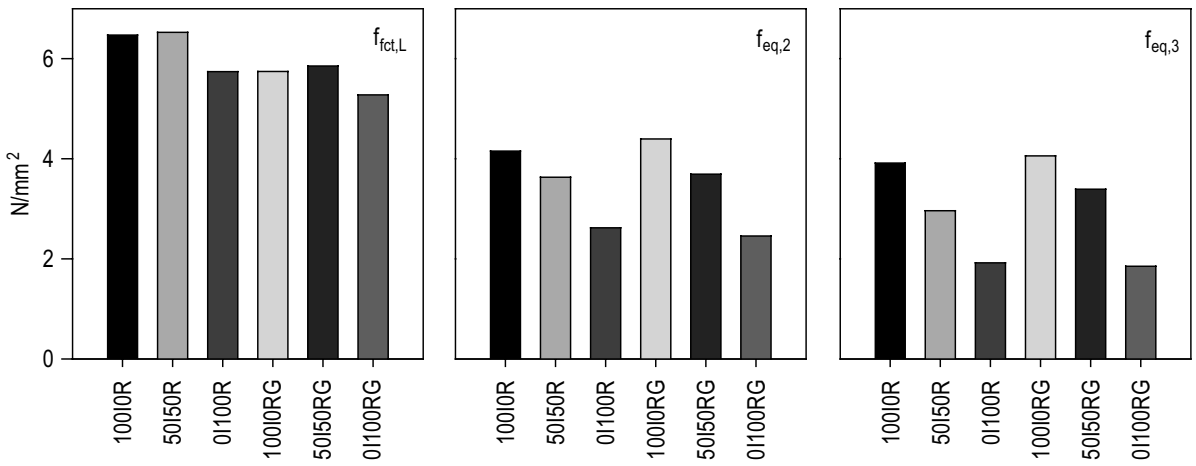

Fig. 11. Design parameters $\mathrm{f}_{\mathrm{fct}}, \mathrm{f}_{\text {eq2 }}$ and $\mathrm{f}_{\text {eq } 3}$ defined by RILEM TC 162-TDF
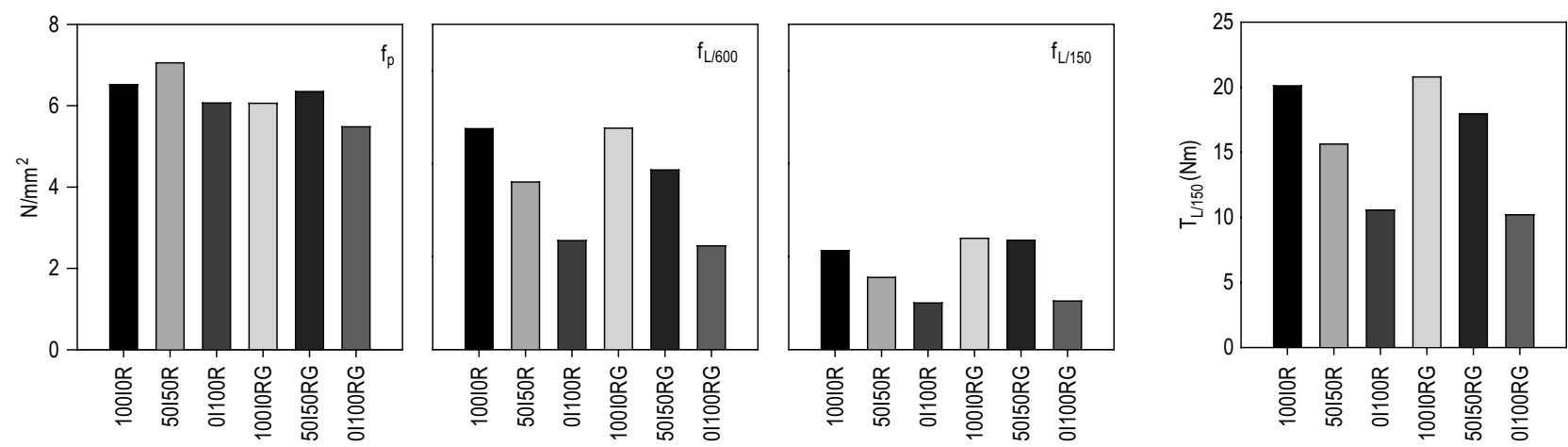

Fig. 12. Design parameters $\mathrm{f}_{\mathrm{p}}, \mathrm{f}_{\mathrm{L} / 600}, \mathrm{f}_{\mathrm{L} / 150}$ and $\mathrm{T}_{\mathrm{L} / 150}$ defined by ASTM C1609

\section{Impact resistance}

The impact resistance of RHFRC was tested using the instrumented drop weight impact resistance test. Test results are reported as specific energy consumed for the initiation of first cracks per unit volume. Dynamic force records over time for the specimen 100I0R (35 drops) are shown in Fig. 13.

The record of force over time is obtained at each "repeated impact", together with visual inspection, in order to detect initiation of cracks on the specimen surface. First or initial crack $\left(\mathrm{N}_{\mathrm{i}}\right)$ on specimen surface usually occurs after approximately 10 to 20 blows. Further loading was continued until the complete breakdown of the specimen. The recorded number of blows which caused breakdown $\left(\mathrm{N}_{\mathrm{u}}\right)$ is expressed as the ultimate impact strength of the specimen.

The complete breakdown of the specimen occurs when crack has propagated throughout the cross section, or at actual full fracture of the specimen. Test results are reported as specific energy consumed for the initiation of the first cracks per unit volume.

The analysis of the results shows that the concrete energy absorption capacity decreases with incorporation of recycled steel fibres and their higher ratio to industrial ones in mixtures without rubber particles (Fig. 14). In order to improve lower impact resistance of FRC with recycled steel fibres, rubber particles have been incorporated in the mixture. Their high capability to absorb energy assures improvement of concrete impact resistance,

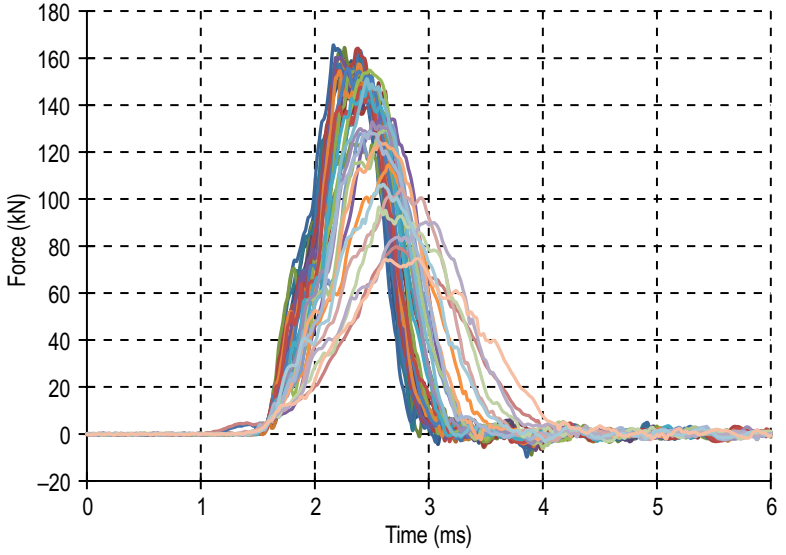

Fig. 13. Force records over time (specimen 100I0R, all impacts)

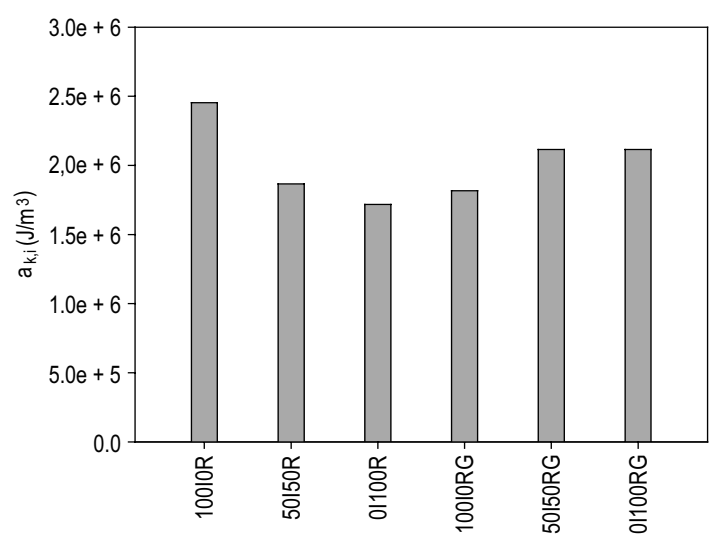

Fig. 14. Specific energy consumed for the initiation of first cracks per unit volume 
especially in mixtures with recycled fibres. For example, by comparing mixtures 50I50R and 50I50RG it can be observed that the capacity to absorb impact energy is $10 \%$ higher in case of mixtures with rubber.

\section{Conclusions}

The research presented in this paper focuses on positive interaction of industrial and recycled steel fibres with rubber particles to be used in construction of high speed railways. According to previous experience, it is obvious that the normally applied concrete presents many disadvantages when used for the above mentioned purpose. The presence of dynamic load calls for the use of concrete capable of absorbing significant energy, in order to prolong service life of the structure. The high strength fibre reinforced concrete is investigated because of its capability to control crack opening and, consequently, to achieve adequate durability.

High price of industrially produced steel fibres (approximately $1.500 € /$ ton) is one of the reasons why this composite is not usually applied. Since any kind of waste tyres disposal is forbidden since 2006, by-products from their recycling process (rubber, steel and textile fibres) are investigated as replacement for the normally used concrete components. During this research, a positive interaction between industrial and recycled steel fibres was investigated.

By analysing mechanical properties of the RHFRC, positive interaction between industrial and recycled steel fibres can be confirmed when compared to the mixtures incorporating recycled fibres only. A low elastic modulus of rubber particles causes a decrease in elastic modulus of the composite, and a slight decrease in compressive strength. The interaction between industrial and recycled steel fibres has no influence on the compressive strength or elastic modulus of concrete. Accordingly, recycled steel fibres have great potential when interacting with industrial steel fibres. Their irregular shape and dimensions result in lower toughness and impact resistance of the composite, but the enhancement of ductility, impact resistance and post-cracking behaviour can be assured if a small quantity of rubber particles is added. Taking into account the fact that recycled steel fibres are 10 times cheaper than the industrially produced ones, the price per $\mathrm{m}^{3}$ of concrete can be reduced by 20 to $50 \%$ if such fibres are added to the composite.

More research should be conducted before structural application of RHFRC. This includes investigation of durability properties of RHFRC to obtain the full profile of the material. Additional investigations are currently under way.

\section{Notation}

The following symbols are used in this paper:

$L=$ support span

LVDT = Linear Variable Differential Transformer, inductive displacement transducer
$F=$ applied force;

$\delta=$ deflection of the center of beam;

$a_{0}=$ initial notch length;

$I_{5}=$ toughness index; the number obtained by dividing

the area up to a deflection of 3.0 times the first-crack

deflection by the area up to first crack;

$I_{10}=$ toughness index, the number obtained by dividing the area up to a deflection of 5.5 times the first-crack deflection by the area up to first crack;

$I_{20}=$ toughness index, the number obtained by dividing the area up to a deflection of 10.5 times the first-crack deflection by the area up to first crack;

$R_{5,10}=$ residual strength factor; the number obtainedby calculating the value of $20\left(I_{10}-I_{5}\right)$;

$R_{10,20}=$ residual strength factor; the number obtained by calculating the value of $10\left(I_{20}-I_{10}\right)$;

$f_{p}=$ peak strength, the stress value obtained for the peak load;

$f_{L / 600}=$ residual strength; the stress value corresponding to a net deflection equal to L/600 of the span;

$f_{L / 150}=$ residual strength; the stress value corresponding to a net deflection equal to L/150 of the span;

$T_{L / 150}=$ specimen toughness; the energy equivalent to the area under the load-deflection curve up to a net deflection of L/150 of the span;

$f_{e q}=$ equivalent tensile strength;

$f_{c t, L}=$ stress at the limit of proportionality;

$N_{i}=$ first or initial crack on specimen surface;

$N_{u}=$ ultimate impact strength of the specimen;

$a_{k, i}=$ specific energy consumed for the initiation of first cracks per unit volume.

\section{References}

Achilleos, C.; Hadjimitsis, D.; Neocleous, K.; Pilakoutas, K.; Neophytou, P. O.; Kallis, S. 2011. Proportioning of steel fibre reinforced concrete mixes for pavement construction and their impact on environment and cost, Sustainability 3(7): 965-983. http://dx.doi.org/10.3390/su3070965

ACI Committee 544. 2009. Measurement of properties of fiber reinforced concrete (ACI 544.2R-89).

Aiello, M. A.; Leuzzi, F.; Centonze, G.; Maffezzoli, A. 2009. Use of steel fibres recovered from waste tyres as reinforcement in concrete: pull-out behaviour, compressive and flexural strength, Waste Management 29(6): 1960-70.

American Society for Testing and Materials. 1998. Standard test method for flexural toughness and first-crack strength of fiber-reinforced concrete (C 1018-97).

American Society for Testing and Materials. 2008. Standard test method for flexural performance of fibre-reinforced concrete (using beam with third-point loading) (ASTM C 1609/C 1609M - 05).

Angelakopoulos, H.; Neocleous, K.; Pilakoutas, K. 2011. Uniaxial compressive behaviour of steel fibre reinforced roller compacted concrete, in Proc. of $6^{\text {th }}$ International Conference Fibre Concrete, 2011, Prague, Czech Republic.

Aules, W. A. 2011. Utilization of crumb rubber as partial replacement in sand for cement mortar, European Journal of Scientific Research 51(2): 203-210.

Barr, B. I. G.; Lee, M. K. with contributions Place, E. J.; Dupont, D.; Erdem, E.; Schaerlaekens, S.; Schnutgen, B.; Stang, H.; Vandewalle, L. 2003b. RILEM TC 162-TDF: Test and design methods for steel fibre reinforced con- 
crete - Round-robin analysis of the R I L E M TC 162TDF beam- bending test: Part 1 - Test method evaluation, Materials and Structures 36 (November): 609-620. http://dx.doi.org/10.1007/BF02483281

Barr, B. I. G.; Lee, M. K. with contributions, Place, E. J.; Dupont, D.; Erdem, E.; Schaerlaekens, S.; Schnutgen, B.; Stang, H.; Vandewalle, L. 2003a. Round-robin analysis of the R I L E M TC 162-TDF beam- bending test: Part 2 - Approximation of 8 from the $\mathrm{C} \mathrm{M} \mathrm{O} \mathrm{D}$ response, $\mathrm{Ma}$ terials and Structures 36 (November): 621-630. http://dx.doi.org/10.1007/BF02483282

Benazzouk, A.; Douzane, O.; Mezreb, K.; Queneudec, M. 2006. Physico-mechanical properties of aerated cement composites containing shredded rubber waste, Cement and Concrete Composites 28(7): 650-657.

http://dx.doi.org/10.1016/j.cemconcomp.2006.05.006

Bjegovic, D.; Baricevic, A.; Lakusic, S. 2012a. Rubberized hybrid fibre reinforced concrete in microstructural-related durability of cementitious composites, in RILEM Proceedings PRO 83, 2012, Amsterdam, Netherlands.

Bjegovic, D.; Baricevic, A.; Lakusic, S. 2012b. Innovative low cost fiber-reinforced concrete. Part I: Mechanical and durability properties, in Proc. of the $3^{\text {rd }}$ International Conference on Concrete Repair, Rehabilitation and Retrofitting, September 2012, Cape Town, South Africa, 199-203.

Bjegovic, D.; Baricevic, A.; Lakusic, S. 2012c. Mechanical properties of high strength concrete with recycled steel fibres from waste tyres, in Proc. of the $8^{\text {th }}$ RILEM International Symposium on Fibre Reinforced Concrete: Challenges and Opportunities (BEFIB 2012), Guimarães, Portugal.

Bjegović, D.; Baričević, A.; Serdar, M. 2011. Durability properties of concrete with recycled waste tyres, in Proc. of the $12^{\text {th }}$ International Conference on Durability of Building Materials and Components, 2011, Porto, Portugal, 1659-1667.

Bjegovic, D.; Lakusic, S.; Serdar, M.; Baricevic, A. 2010. Properties of concrete with components from waste tyre recycling, in Concrete Structures for Challenging Times, Marianske Lazne, 2010, Praha, Czech Republic, 134-140.

Chen, L.; Mindess, S.; Morgan, D. R.; Shah, S. P.; Johnston, C. D.; Pigeon, M. 1995. Comparative toughness testing of fiber reinforced concrete, in Testing of fiber reinforced concrete. Salt Lake City, Utah: American Concrete Institute, 41-75.

Council of the European Union [online]. 1999. Council Directive 1999/31/EC of 26 April 1999 on the landfill of waste [cited 16 August 2011]. Available from Internet: http:// eur-lex.europa.eu/LexUriServ/LexUriServ.do?uri=O$\mathrm{J}: \mathrm{L}: 1999: 182: 0001: 0019: \mathrm{EN}: \mathrm{PDF}$

Domagała, L. 2011. Modification of properties of structural lightweight concrete with steel fibres, Journal of Civil Engineering and Management 17(1): 36-41. http://dx.doi.org/10.3846/13923730.2011.553923

Gopalaratnam, V. S.; Shah, S. P.; Batson, G. B.; Criswell, M. E.; Ramakrishnan, V.; Wecharatana, M. 1991. Fracture toughness of fibre reinforced concrete, ACI Materials Journal 88(4): 339-353.

Graeff, A. G.; Pilakoutas, K.; Lynsdale, C.; Neocleous, K. 2009. Corrosion durability of recycled steel fibre reinforced concrete, Intersection 6(7): 77-89.

Graeff, A. G.; Pilakoutas, K.; Neocleous, K.; Peres, M. V. 2012. Fatigue resistance and cracking mechanism of concrete pavements reinforced with recycled steel fibres recovered from post-consumer tyres, Engineering Structures 45: 385-395. http://dx.doi.org/10.1016/j.engstruct.2012.06.030

Guneyisi, E.; Gesoglu, M.; Ozturan, T. 2004. Properties of rubberized concretes containing silica fume, Cement and
Concrete Research 34(12): 2309-2317.

http://dx.doi.org/10.1016/j.cemconres.2004.04.005

Jingfu, K.; Chuncui, H.; Zhenli, Z. 2008. Strength and shrinkage behaviors of roller-compacted concrete with rubber additives, Materials and Structures 42(8): 1117-1124. http://dx.doi.org/10.1617/s11527-008-9447-x

Karihaloo, B. L. 1995. Fracture mechanics and structural concrete. New York: Longman Scientific \& Technical, Wiley. $346 \mathrm{p}$.

Khaloo, A. R.; Dehestani, M.; Rahmatabadi, P. 2008. Mechanical properties of concrete containing a high volume of tire-rubber particles, Waste Management 28(12): 24722482.

Khorami, M.; Ganjian, E.; Vafaii, A. 2007. Mechanical properties of concrete with waste tire rubbers as coarse aggregates, in Proc. of the Special Sections on International Conference on Sustainable Construction Materials and Technologies, Coventry University, 85-90.

Kim, D.; Naaman, A. E.; El-Tawil, S. 2008. Comparative flexural behavior of four fiber reinforced cementitious composites, Cement and Concrete Composites 30(10): 917928. http://dx.doi.org/10.1016/j.cemconcomp.2008.08.002

Krolo, J.; Bjegovic, D.; Damjanovic, D.; Duvnjak, I.; Baricevic, A. 2012. Innovative low cost fibre-reinforced concrete. Part II: Fracture toughness and impact strength, in Proc. of the $3^{\text {rd }}$ International Conference on Concrete Repair, Rehabilitation and Retrofitting, September, 2012, Cape Town, South Africa, 204-209.

Lakušić, S.; Baričević, A.; Damjanović, D.; Duvnjak, I.; Haladin, I. 2012. Slab track system - ECOTRACK ECOTRACK in construction of transport infrastructure. Zagreb: University of Zagreb, Faculty of Civil Engineering, Department of Transportation, 7-49.

Lakušić, S.; Bjegović, D.; Baričević, A.; Haladin, I. 2011. Development of high performance concrete for high speed railways, in Proc. of the $25^{\text {th }}$ Congress and International Symposium about Research and Application of Modern Achievements in Civil Engineering in the Field of Materials and Structures, 2011, Beograd, Serbia, 81-88.

Li, G.; Stubblefield, M. A.; Garrick, G.; Eggers, J.; Abadie, C.; Huang, B. 2004. Development of waste tire modified concrete, Cement and Concrete Research 34(12): 2283-2289. $\mathrm{http}: / / \mathrm{dx}$. doi.org/10.1016/j.cemconres.2004.04.013

Marques, A. C.; Akasaki, J. L.; Trigo, A. P. M.; Marques, M. L. 2008. Influence of the surface treatment of tire rubber residues added in mortars, Ibracon Structures and Materials Journal 1(2): 113-120.

Marques, A. C.; Marques, M. L.; Akasaki, J. L.; Trigo, A. P. M. 2004. Study of treated and untreated tire rubber mortar, in Proc. of the International RILEM Conference on the Use of Recycled Materials in Buildings and Structures, Barcelona, Spain, 455-462.

Mindess, S.; Rieder, K. A. 1999. Size effects on plain and fiber reinforced concretes at high loading rate, in the Proc. of the International Conference on Composite Materials 12 Europe, 1999, Paris, France.

Neocleous, K.; Tlemat, H.; Pilakoutas, K. 2006. Design issues for concrete reinforced with steel fibers, including fibers recovered from used tires, Journal of Materials in Civil Engineering 18(5): 677-685.

http://dx.doi.org/10.1061/(ASCE)0899-1561(2006)18:5(677)

Neocleous, K.; Angelakopoulos, H.; Pilakoutas, K.; Guadagnini, M. 2011. Fibre-reinforced roller-compacted concrete transport pavements, in Proceedings of the ICE - Transport 164(2): 97-109.

Nguyen, T. H.; Toumi, A.; Turatsinze, A. 2010. Mechanical properties of steel fibre reinforced and rubberised cement-based mortars, Materials \& Design 31(1): 641-647. http://dx.doi.org/10.1016/j.matdes.2009.05.006 
Papakonstantinou, C. G.; Tobolski, M. J. 2006. Use of waste tire steel beads in Portland cement concrete, Cement and Concrete Research 36(9): 1686-1691. http://dx.doi.org/10.1016/j.cemconres.2006.05.015

Pilakoutas, K.; Neocleous, K.; Tlemat, H. 2004. Reuse of tyre steel fibres as concrete reinforcement, in Proc. of the ICE: Engineering Sustainability 157(3): 131-138. http://dx.doi.org/10.1680/ensu.2004.157.3.131

RILEM TC 162 - TDF. 2002. Test and design methods for steel fibre reinforced concrete. Bending test - Final Recommendation, Materials and Structures 35(November): $579-582$.

Segre, N.; Joekes, I. 2000. Use of tire rubber particles as addition to cement paste, Cement and Concrete Research 30: 1421-1425. http://dx.doi.org/10.1016/S0008-8846(00)00373-2

Segre, N.; Monteiro, P. J. M.; Sposito, G. 2002. Surface characterization of recycled tire rubber to be used in cement paste matrix, Journal of Colloid and Interface Science 248(2): 521-523. http://dx.doi.org/10.1006/jcis.2002.8217
Skazlić, M.; Bjegović, D. 2009. Toughness testing of ultra high performance fibre reinforced concrete, Materials and Structures 42: 1025-1038. http://dx.doi.org/10.1617/s11527-008-9441-3

Tlemat, H.; Pilakoutas, K.; Neocleous, K. 2004. Demonstrating steel fibres from waste tyres as reinforcement in concrete: Material Characterisation in Proc. of First International Conference on Innovative Materials and Technologies for Construction and Restoration, Varenna, Italy, 172-185.

Turatsinze, A.; Bonnet, S.; Granju, J. 2005. Mechanical characterisation of cement-based mortar incorporating rubber aggregates from recycled worn tyres, Building and Environment 40(2): 221-226. http://dx.doi.org/10.1016/j.buildenv.2004.05.012

Turatsinze, A.; Granju, J.; Bonnet, S. 2006. Positive synergy between steel-fibres and rubber aggregates: effect on the resistance of cement-based mortars to shrinkage cracking, Cement and Concrete Research 36(9): 1692-1697. http://dx.doi.org/10.1016/j.cemconres.2006.02.019

Dubravka BJEGOVIC. Prof,. Head of Materials Technology Chair at the Department of Materials at the University of Zagreb, Faculty of Civil Engineering and Assistant General Manager for R\&D of IGH. Has a long experience in scientific projects (COST projects 521, 530 and 534, FP6 STREP - ARCHES, CIP Eco Innovation - RUCONBAR, was project coordinator of EUREKA project FIRE_TUNNEL EUREKA project FIRECON and LIFE project). Author and co-author of 1 book, 15 book chapters and more than $20 \overline{0}$ scientific papers.

Ana BARICEVIC. She is a PhD candidate and teaching assistant at the Department of Materials at the University of Zagreb, Faculty of Civil Engineering. She is actively involved in national and international projects (FP6 STREP - ARCHES, CIP Eco Innovation RUCONBAR, "Concrete track systems - ECOTRACK"). As author and co-author until today she has published 2 book chapters and 20 scientific papers. Her main research interest includes application of waste materials in concrete especially by-products from mechanical recycling of waste tyres.

Stjepan LAKUSIC. Head of Chair for Railways and Professor in the Department of Transportation, at the University of Zagreb, Faculty of Civil Engineering. He is included in more than 20 professional projects in the field of noise protection and noise measuring on highways, railways and especially in urban areas, as main designer. Author and co-author of 7 books, 22 book chapters and more than 120 scientific papers. He is currently coordinating EU project "Rubberized concrete noise barriers - RUCONBAR" financed by CIP ECO Innovation fund.

Domagoj DAMJANOVIC. He is an Assistant Professor at the Department of Engineering Mechanics at the University of Zagreb, Faculty of Civil Engineering. He is currently actively involved in national and international scientific projects (Development of Experimental Methods in research of CE structures - National project funded by Croatian Ministry of Science, Climate for culture - FP7 project). As author and co-author until today he has published 1 book chapter and 35 scientific papers. His main research interests include statical and dynamical experimental testing of CE structures and structural elements as well as their theoretical and numerical analysis.

Ivan DUVNJAK. He is a PhD candidate and teaching assistant at the Department of Engineering Mechanics at the University of Zagreb, Faculty of Civil Engineering. He is currently actively involved in national scientific projects (Development of Experimental Methods in research of CE structures - National project funded by Croatian Ministry of Science). As author and co-author until today he has published 1 book chapter and 10 scientific papers. His main research interests include structural health monitoring, statical and dynamical experimental testing of CE structures and structural elements. 